Kane, E. A., Jacobson, W. C. \& Moore, L. A. (1950). F. Nutr. 4I, $5^{83}$.

Mäkelä, A. (1956). Suom. Maataloust. Seur. Fulk. no. 85.

Marshall, R. A. (1949). Brit. F. Nutr. 3, I.

Norman, A. G. \& Jenkins, S. H. (1933). Biochem. $7.27,218$.

Norman, A. G. \& Jenkins, S. H. (1934a). Biochem. F. 28, 2147.

Norman, A. G. \& Jenkins, S. H. (1934b). Biochem. F. 28, 2160.

Schalk, A. F. \& Amadon, R. S. (1928). Bull. N. Dak. agric. Exp. Sta. no. 216.

\title{
The digestion of foodstuffs in the stomach of the sheep and the passage of digesta through its compartments
}

\section{Nitrogenous compounds}

\author{
By F. V. GRAY, A. F. PILGRIM ANd R. A. WELLER \\ Division of Biochemistry and General Nutrition of the Commonwealth Scientific \\ and Industrial Research Organization, University of Adelaide, South Australia
}

(Received 22 April I958)

In recent years important advances have been made in our understanding of the digestion of nitrogenous compounds by ruminants, and it is now known that very extensive changes take place in such compounds before the arrival of digesta in the abomasum and small intestine. Among these changes is the formation of ammonia in the rumen, to an extent which leads to its accumulation there in amounts that vary markedly according to the nature of the nitrogenous compounds eaten (McDonald, I $948,195^{2}$ ). It has been demonstrated that ammonia can readily be absorbed from the rumen into the blood stream (McDonald, 1948) and it is therefore clearly important to establish the extent to which this phenomenon occurs under various feeding regimes. The formation and absorption of large quantities of ammonia might perhaps be indicative of a serious wastage of nitrogen in the animal's economy.

The mere concentration of ammonia in the rumen cannot indicate accurately the extent of its formation, and it would undoubtedly be difficult to measure directly the amount of nitrogen passing through the rumen wall. With the aid of a suitable marker in the fodder and digesta, however, it may be possible to calculate the quantity of nitrogen reaching the abomasum and small intestine during the feeding cycle. In the experiments described below lignin (L) has been used as such a marker.

\section{EXPERIMENTAL}

Nitrogen and lignin in the stomach compartments

In the first paper of this series (Gray, Pilgrim \& Weller, 1958) details of the feeding and slaughtering of a number of Merino sheep have been described. The same animals provided values for the present work, but an additional number of sheep were included in the group fed on lucerne hay. The experimental rations, which were selected 
to contain widely differing amounts of nitrogen, were: (I) $500 \mathrm{~g}$ wheaten hay and $250 \mathrm{~g}$ wheat straw $(\mathrm{N}=0.7 \%),(2) 800 \mathrm{~g}$ wheaten hay $(\mathrm{N}=\mathrm{I} \cdot \mathrm{I} \%),(3) 400 \mathrm{~g}$ wheaten hay and $400 \mathrm{~g}$ lucerne hay $(\mathrm{N}=\mathrm{I} \cdot 8 \%$ ) and $(4) 800 \mathrm{~g}$ lucerne hay $(\mathrm{N}=2 \cdot 9 \%)$.

Sampling of the digesta in the stomach compartments, preparation of the samples for analysis, and the method used for the determination of lignin, have also been described by Gray et al. (I958). Nitrogen was determined by the Kjeldahl method in the alcohol-precipitated solids and in the clear alcoholic filtrates.

\section{Ammonia in the rumen}

In addition to the animals in the four groups that were slaughtered, other sheep were used for the determination of ammonia in the rumen fluid. They were given rations of wheaten hay and lucerne hay similar to rations 2 and 4 , for several weeks before the rumen fluid was examined. Samples were drawn directly from the rumen by hypodermic syringe and the ammonia in them was determined by the microdiffusion method of Conway ( 1947 ), with potassium metaborate as the alkaline reagent.

\section{RESULTS}

In Table I are listed the ratios of nitrogen to lignin in the rumen, omasum and abomasum of the sheep fed on rations $1-3$. In Fig. I the ratios in the abomasum, expressed as percentages of the ratios in the respective fodders, are plotted so that the values throughout the day can be compared and mean values for the day can be estimated. These mean values have been used to calculate the corresponding amounts

\section{Table I. Nitrogen:lignin ratios in the stomach compartments of sheep}

\begin{tabular}{|c|c|c|c|c|c|c|c|c|}
\hline \multirow[b]{2}{*}{ Ration } & \multirow{2}{*}{$\begin{array}{l}\text { Time } \\
\text { after } \\
\text { beginning } \\
\text { of } \\
\text { feeding } \\
\text { (h) }\end{array}$} & \multicolumn{3}{|c|}{$\begin{array}{c}\text { Nitrogen } \\
\text { (mg/roo g digesta) }\end{array}$} & \multicolumn{4}{|c|}{$\begin{array}{l}\text { Ratio, N:L* } \\
(\mathrm{mg} N / \mathrm{g} \mathrm{L})\end{array}$} \\
\hline & & Rumen & Omasum & $\begin{array}{c}\text { Ab- } \\
\text { omasum }\end{array}$ & Rumen & Omasum & $\begin{array}{c}\text { Ab- } \\
\text { omasum }\end{array}$ & Ration \\
\hline \multirow{4}{*}{$\begin{array}{l}\text { Wheaten hay } \\
\text { and wheat } \\
\text { traw }\end{array}$} & 5 & I $5^{8}$ & 275 & I 17 & 90 & 97 & $87)$ & \multirow{4}{*}{75} \\
\hline & 10 & I39 & 279 & 127 & 84 & 95 & 80 & \\
\hline & 17 & I33 & 230 & 129 & 89 & 86 & $98\}$ & \\
\hline & 24 & 87 & 200 & 107 & 64 & 72 & $8_{3}$ & \\
\hline \multirow[t]{7}{*}{ Wheaten hay } & 2 & I 80 & 284 & 155 & 103 & 90 & $119)$ & \multirow{7}{*}{ I 27} \\
\hline & 5 & 199 & 382 & 158 & 123 & I II & I 18 & \\
\hline & 7 & 182 & 344 & 180 & 119 & I 2 I & 129 & \\
\hline & 10 & I 48 & 347 & 147 & 102 & 122 & 123 & \\
\hline & 16 & $\mathrm{I} 84$ & $33^{6}$ & I 65 & 107 & I 2 I & 147 & \\
\hline & 24 & 141 & 236 & 148 & I 5 & 80 & 126 & \\
\hline & 24 & IO4 & 269 & I 21 & 116 & 96 & 120 & \\
\hline \multirow{5}{*}{$\begin{array}{l}\text { Wheaten hay } \\
\text { and lucerne } \\
\text { hay }\end{array}$} & 3 & $2 I I$ & 493 & 177 & I 84 & 133 & 135 & 222 \\
\hline & 5 & 269 & 472 & $\mathrm{I} 82$ & I57 & I 74 & 168 & 239 \\
\hline & ro & 282 & 502 & 195 & 172 & I 68 & 162 & 239 \\
\hline & I6 & 210 & 449 & 225 & 165 & I 5 I & 170 & 239 \\
\hline & 24 & 148 & 349 & I 39 & 124 & II 5 & 126 & 239 \\
\hline
\end{tabular}

\footnotetext{
* Values for the concentrations of lignin in the digesta have been reported by Gray et al. (1958).
} 
of nitrogen passed from the abomasum to the duodenum, and the results are given in Table 2. In Table 3 are the results of the trials conducted on ration 4 . The results of the ammonia determinations in the rumen fluid are represented graphically in Fig. 2.

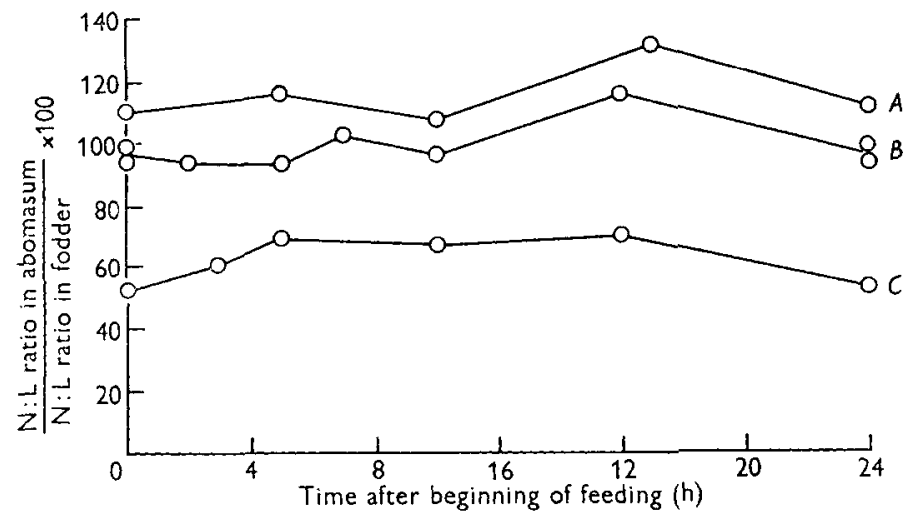

Fig. I. Nitrogen: lignin ratios in the abomasum of sheep, expressed as percentages of the ratios in the fodders. $A$, ration I $(\mathrm{N}=0.7 \%) ; B$, ration $2(\mathrm{~N}=\mathrm{I} \cdot \mathrm{I} \%) ; C$, ration $3(\mathrm{~N}=1.8 \%)$.

Table 2. Nitrogen calculated to have passed from the abomasum to the duodenum of the sheep each day

\begin{tabular}{|c|c|c|c|c|c|}
\hline Ration & $\begin{array}{l}\text { Nitrogen } \\
\text { from food } \\
(\mathrm{g})\end{array}$ & $\begin{array}{l}\text { Lignin } \\
\text { from food } \\
\text { (g) }\end{array}$ & $\begin{array}{c}\text { Mean } \\
\text { ratio in } \\
\text { abomasum } \\
(\text { na N/g L) }\end{array}$ & $\begin{array}{l}\text { Nitrogen } \\
\text { passed to } \\
\text { duodenum } \\
\quad(\mathrm{g})\end{array}$ & $\begin{array}{l}\text { Percentage } \\
\text { of dietary } \\
\text { nitrogen } \\
\text { represented }\end{array}$ \\
\hline $\begin{array}{l}\text { heaten hay } \\
\text { and wheat straw }\end{array}$ & $5 \cdot 2$ & 70 & 87 & $6 \cdot 1$ & II 7 \\
\hline Theaten hay & 8.8 & 69 & 127 & $8 \cdot 8$ & 100 \\
\hline Theaten hay & $14: 4$ & 60 & 155 & $9 \cdot 3$ & 65 \\
\hline
\end{tabular}

and lucerne

hay

Lucerne hay

$23 \cdot 2$

59

$[188]^{*}$

II I I

$4^{8}$

* Determined from composite sample.

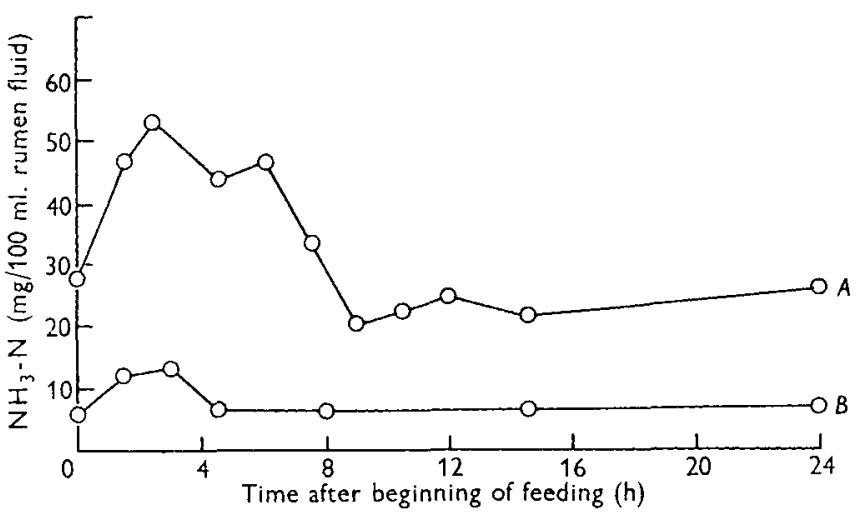

Fig. 2. Ammonia in the rumen fluid of sheep fed on wheaten hay and on lucerne hay. $A$, lucerne hay; $B$, wheaten hay. 
Table 3. Nitrogen:lignin ratios ( $\mathrm{mg} \mathrm{N} / \mathrm{g} L)$ in the stomach of sheep fed on lucerne hay (ratio, $\left.N: L=39^{\circ}\right)$

Time after
beginning of beginning of
feeding (h)

Ratio, N:L

$\begin{array}{ccc}\text { Rumen } & \text { Omasum } & \begin{array}{c}\text { Abomasum } \\ 257\end{array} \\ 224 & 132 & 140 \\ 224 & 135 & 263 \\ 275 & 143 & 204 \\ 220 & 160 & 143 \\ 226 & 141 & 263 \\ 198 & 146 & 173 \\ 244 & 179 & 187 \\ 220 & 161 & 230 \\ 274 & 180 & 260 \\ 277 & 215 & 180 \\ 206 & 156 & 262 \\ - & -- & 134 \\ 170 & 187 & 322 \\ 202 & 185 & 360 \\ - & 215 \\ 140 & 154 & 215 \\ 187 & 199 & 193 \\ 124 & 132 & 139 \\ 127 & 123 & 230 \\ - & - & 182 \\ 150 & 147 & 150 \\ 131 & 146 & 171 \\ & & \text { Total }\end{array}$

Composition of abomasal contents

\begin{tabular}{|c|c|}
\hline Nitrogen $(\mathrm{g})$ & Lignin (g) \\
\hline 0.488 & 3.47 \\
\hline 0.233 & $1 \cdot 66$ \\
\hline 0.308 & $1 \cdot 17$ \\
\hline 0.577 & $2 \cdot 83$ \\
\hline 0.542 & $3 \cdot 79$ \\
\hline 0.395 & $1 \cdot 50$ \\
\hline $\begin{array}{l}0.345 \\
0.386\end{array}$ & $\begin{array}{l}1 \cdot 99 \\
2 \cdot 06\end{array}$ \\
\hline 0.535 & $2 \cdot 33$ \\
\hline 0.405 & $r \cdot 56$ \\
\hline 0.747 & $4 \cdot 15$ \\
\hline 0.432 & $I \cdot 65$ \\
\hline 0.937 & 7.00 \\
\hline 0.488 & I. 52 \\
\hline 0.759 & $2 \cdot 10$ \\
\hline $0.36 I$ & $1 \cdot 68$ \\
\hline 0.862 & $4 \cdot 48$ \\
\hline 0.564 & 4.05 \\
\hline 0.429 & 1.86 \\
\hline 0.352 & $1 \cdot 93$ \\
\hline 0.480 & 3.20 \\
\hline 0.724 & 4.23 \\
\hline $\mathrm{II} \cdot 3$ & $60 \cdot 2$ \\
\hline
\end{tabular}

Ratio, N:L in composite sample of abomasal contents $=\mathrm{I} 88$.

DISCUSSION

The primary object of these experiments was to establish how much nitrogen passed from the abomasum to the duodenum each day, in comparison with the amount known to be ingested in the ration. Since each animal was given a constant ration it is presumed that the amount of lignin passing through its abomasum each day must have remained constant, within fairly narrow limits. Under such circumstances measurement of the ratio of nitrogen to lignin in the abomasum at sufficiently frequent intervals provides the necessary data for calculating the amount of nitrogen passing on to the duodenum during the day.

Apart from the quantity of nitrogen consumed in the food there are two factors which must influence the amount that eventually reaches the small intestine, namely absorption of nitrogen from the stomach compartments and influx of extra-dietary nitrogen into them in the saliva and gastric juice. By comparing the nitrogen:lignin $(N: L)$ ratios in the abomasum and fodder with those in the rumen and omasum some light has been thrown on the responsibility of these factors for bringing changes in the ratio during the passage of digesta through the stomach.

The amount of nitrogen passed from the abomasum to the duodenum

Rations $\mathrm{I}-3$. It is clear from Table $\mathrm{I}$ and Fig. $\mathrm{I}$ that when the diet contained little nitrogen (rations $I$ and 2 ) the $N: L$ ratio in the abomasum was nearly as high as, or somewhat higher than, the ratio in the fodder throughout almost the whole day. The 
amount of nitrogen passing on from the abomasum was therefore equivalent to a large proportion of, or was actually a little greater than, the amount in the food. On the other hand, in animals fed on ration 3 , containing $1.8 \%$ nitrogen, the abomasal ratios were much less throughout the day than the ratio in the fodder, indicating that the amount of nitrogen passing to the duodenum was correspondingly less than that in the food. The approximate quantities involved are given in Table 2. It will be realized that the accuracy of the mean values adopted for the $\mathrm{N}: \mathrm{L}$ ratios is dependent on the number of samples examined, and that the validity of the whole procedure is dependent on the contents of the abomasum being representative of the digesta passing through it in the periods between sampling. The latter condition is likely to be most nearly met when there is a minimum of change in composition in successive samples. Though the actual amounts calculated can be only approximate in view of the number of samples available and because each sample was taken from a different animal, there can be no doubt about the general conclusion that the proportion of the dietary nitrogen reaching the small intestine varied greatly with the nature of the food, being near to $100 \%$ with the low-nitrogen diets and falling to less than $70 \%$ when the nitrogen content of the ration was increased.

Ration 4. In a preliminary report of this work (Gray \& Pilgrim, r956) results for the abomasum were quoted for a series of six sheep fed on lucerne hay. The findings were similar to those now obtained for ration 3 , but implied that nitrogen equivalent to only about $40 \%$ of the dietary nitrogen reached the abomasum and small intestine. An extension of the experiment to samples of lucerne hay cut at different times showed, however, that there was a considerable number of animals that had relatively small quantities of solids in the abomasum when slaughtered, and these samples of digesta often exhibited a ratio of nitrogen to lignin much higher than those already reported. The quantity of digesta in the abomasum and the $N: L$ ratios in it were found to vary considerably.

It has been pointed out that the validity of the procedure used for calculation of the nitrogen reaching the small intestine depended on the abomasal samples being representative of the digesta passing through the organ in the periods between sampling. It became clear that a small number of animals fed on lucerne hay could not be considered suitable in this respect. The number of sheep in the series was therefore increased as far as practicable, and samples taken at many different times of the day were pooled to give a composite sample which, in its total lignin content, represented a large part (nearly the whole) of the lignin in a day's ration. It may well be that an even larger number of samples would be required to establish firmly the amount of nitrogen reaching the duodenum, and it is desirable that the findings should be checked by some other method. Nevertheless, the results (Table 3) are given here because they agree fairly closely with those previously reported. The $N: L$ ratio in the composite sample implied that the amount of nitrogen passing from the abomasum to the duodenum was equivalent to about $48 \%$ of the dietary nitrogen. 


\section{Factors influencing the passage of nitrogen through the stomach}

The differences between the amounts of nitrogen given in the food and the amounts reaching the duodenum will be considered in the light of the $\mathrm{N}: \mathrm{L}$ ratios determined simultaneously, in each of the stomach compartments, but first it is necessary to discuss the quantities of extra-dietary nitrogen that may be involved through the more or less continuous secretion of saliva and gastric juice, and also to discuss the implication of the ammonia present in the rumen.

Extra-dietary nitrogen. Although precise measurements of the normal flow of saliva have not yet proved possible, it appears that the sheep secretes some 4-71. daily (cf. Marston, 1948) in which the concentration of nitrogen may range from about to to $35 \mathrm{mg} \mathrm{N} / 100 \mathrm{ml}$. (McDougall, 1948). The total salivary nitrogen may therefore be considered to be of the order of $0.5^{-2} \mathrm{~g}$ daily. This amount is small compared with the maximum intake of fodder nitrogen in our experiments, but is relatively large when compared with that provided by the first ration, only $5.2 \mathrm{~g}$ daily. Again, there is no doubt that a considerable volume of gastric juice is poured into the abomasum. Comparison of the concentration of solids in the omasum (18-20\%) with that in the abomasum (5-10\%) suggests that omasal digesta are diluted by an equal or larger volume of gastric juice (cf. Garton, 195I; Masson \& Phillipson, I952). Unfortunately, there is little information available concerning the amount of nitrogen involved. Grosser (1905) found $0.0526 \%$ in the gastric juice of a goat and McDonald (1954) measured $0.004 \%$ in the juice secreted by a sheep, but it is not known to what extent the amount may vary with diet or with time of day.

Absorption of ammonia. McDonald (1948) calculated that ammonia was absorbed at a rate equivalent to $4.3 \mathrm{~g} \mathrm{~N} / 24 \mathrm{~h}$ from a rumen which had been filled with a solution containing $22 \cdot 6 \mathrm{mg} \mathrm{N} / 100 \mathrm{ml}$. From Fig. 2 it can be seen that in a sheep fed on lucerne hay, the concentration of ammonia in the rumen fluid was probably never less than $20 \mathrm{mg} \mathrm{N} / 100 \mathrm{ml}$, and for some $8 \mathrm{~h}$ after feeding it was much greater, reaching a maximum value of more than $5^{\circ} \mathrm{mg} \mathrm{N} / 100 \mathrm{ml}$. It seems clear that such concentrations would be consistent with the absorption of a very considerable proportion of the nitrogen entering the rumen in this fodder. On the other hand, in the sheep fed on wheaten hay the concentration of ammonia remained for the greater part of the day at $5^{-6} \mathrm{mg} \mathrm{N} / 100 \mathrm{ml}$. rumen fluid, and only rose above this value to about $12 \mathrm{mg} /$ $100 \mathrm{ml}$. for $3-4 \mathrm{~h}$ after feeding. The concentrations present in sheep fed on the ration with least nitrogen were not measured, but there can be little doubt that they would be very small indeed.

Comparison of the $N: L$ ratios in the three stomach compartments. It is convenient to deal first with the values for the sheep fed on ration 2 (wheaten hay). It is clear that in the rumen the ratio remained fairly steady throughout the day at a value not much less than in the fodder. This finding is in accordance with the amount of nitrogen calculated to have reached the abomasum, and the expectation that absorption of ammonia from the rumen was small enough to be counterbalanced by the influx of nitrogen in the saliva. Though a fairly constant feature of these experiments was a relatively low N:L ratio in the omasum and abomasum in the last and first samples of the day, a finding 
for which no explanation can be made at present, nevertheless, the substantial uniformity of the ratios in the three compartments, despite occasional variation, suggests that the digesta leaving the rumen must have been a fairly representative sample of its contents in respect to the nitrogen and lignin present. It is not implied, however, that there was no selection of material for passage out of the rumen. It has already been shown by Gray et al. (1958) that, even in the period immediately after feeding, the material reaching the omasum and abomasum must consist largely of well-digested residues of the food. Despite such a selection taking place in the experiments under discussion the $\mathrm{N}: \mathrm{L}$ ratios in the omasum and abomasum would scarcely be affected, since the ratio in the rumen was substantially constant for most of the day.

In the abomasum the secretion of nitrogen in the gastric juice must increase the $\mathrm{N}: \mathrm{L}$ ratio, unless absorption of nitrogen takes place to an equivalent or greater degree. Because the ratios in the three compartments were much the same at any one time, the conclusion to be drawn from these experiments is that the amount of nitrogen absorbed from the organ was not significantly greater than the amount added in the gastric juice.

Before considering the animals fed on lucerne hay it is convenient to mention briefly those on the low-nitrogen diet (the mixture of wheaten hay and wheat straw). There were only four sheep in this experiment, but the limited results show that the $\mathrm{N}: \mathrm{L}$ ratios in the three compartments were nearly all higher than in the fodder. Because of the low nitrogen content of the ration it would be expected that formation and absorption of ammonia would be at a minimum. The increased ratios in the rumen suggest that influx of salivary nitrogen more than counterbalanced what little absorption may have occurred in this organ (cf. Balch, 1957).

When the sheep fed on the rations containing lucerne hay ( 3 and 4 ) are considered it is evident that the results present a different picture in that the N:L ratios in the rumen were at all times much smaller than in the fodders. In view of the relatively high concentration of ammonia in the rumen of sheep fed on lucerne hay, there can be no doubt that at least a considerable part of the difference must be due to the absorption of ammonia from that organ. The question arises, however, whether such absorption accounts for the whole of the difference between the ratio in the fodder and that in the rumen. The only additional cause for a lowered ratio in the rumen would be that nitrogen passed to the omasum more rapidly than lignin, which could happen only if the fluid phase of the digesta passed out more rapidly than the coarse solids which contained the bulk of the lignin. But the continued passage of an excess of nitrogen over lignin would be reflected in increased ratios in the omasum or abomasum. In the sheep fed on ration 3 , containing $50 \%$ lucerne hay, these ratios were not significantly greater than those in the rumen, so in these sheep it appears that the fall in the N:L ratios in the rumen (as compared with the fodder) could be attributed largely to absorption of nitrogen and not to its differential passage ahead of the lignin with which it had been associated.

This view can only be accepted, however, if there was little or no absorption of soluble nitrogenous compounds from the abomasum. Lack of absorption of ammonia from the organ is indicated by the work of McDonald (1948), and it is generally 
agreed that in monogastric animals there is little absorption of products of protein breakdown from the stomach.

Among the sheep fed on lucerne hay alone (ration 4 ), some samples of abomasal contents did exhibit $\mathrm{N}: \mathrm{L}$ ratios higher than those in the rumen, and the possibility therefore remains that it was due to the passage of nitrogen ahead of lignin from the rumen to the abomasum. Nevertheless, the overall picture of the material reaching the abomasum, as reflected in the composite sample, supports the view that, on this ration also, differences between the $\mathrm{N}: \mathrm{L}$ ratios in the rumen and fodder were due largely to absorption of nitrogen through the rumen wall.

\section{SUMMARY}

I. The quantity of nitrogen reaching the abomasum and duodenum has been calculated from the nitrogen:lignin ratios in the fodder and the abomasal contents of thirty-eight Merino sheep slaughtered at intervals after feeding.

2. The amount was calculated to be equivalent to nearly $100 \%$ of the dietary nitrogen for sheep fed on wheaten hay $(\mathrm{N}=\mathrm{I} \cdot \mathrm{I} \%$ ), but only about $65 \%$ for animals fed on a mixture of wheaten hay and lucerne hay $(\mathrm{N}=\mathrm{I} \cdot 8 \%)$ and as little as $48 \%$ for those fed on lucerne hay alone $(\mathrm{N}=2.9 \%)$. An amount in excess of the dietary nitrogen was found to reach the abomasum in sheep fed on a diet of wheaten hay and wheat straw, very low in nitrogen $(0.7 \%)$.

3. The effects of absorption of ammonia into the blood stream, and the influx in the saliva and gastric juice, of extra-dietary nitrogen, are discussed in relation to the nitrogen:lignin ratios found in the rumen, omasum and abomasum of these sheep.

\section{REFERENCES}

Balch, C. C. (1957). Brit. F. Nutr. I1, 213.

Conway, E. J. (1947). Microdiffusion Analysis and Volumetric Error, 2nd ed. London: Crosby, Lockwood and Son Ltd.

Garton, G. A. (1951). Ұ. exp. Biol. 28, 358.

Gray, F. V. \& Pilgrim, A. F. (1956). Nature, Lond., 178, 94.

Gray, F. V. Pilgrim, A. F. \& Weller, R. A. (1958). Brit. F. Nutr. 12, 404.

Grosser, P. (1905). Zbl. Physiol. 19, 265.

McDonald, I. W. (1948). Biochem. F. 42, 584 .

McDonald, I. W. (1952). Biochem. F. 51, 86.

McDonald, I. W. (1954). Biochem. F. 56, 120.

McDougall, E. I. (1948). Biochem. F. 43, 99.

Marston, H. R. (1948). Biochem. F. 42, 564 .

Masson, M. J. \& Phillipson, A. T. (1952). F. Physiol. r16, 98. 